\title{
Expanding the description of Bionia bella Mart. ex Benth. (Leguminosae, Papilionoideae)
}

\author{
José Martins Fernandes ${ }^{1,3}$ and Flávia Cristina Pinto Garcia ${ }^{2}$
}

Received: 5 August, 2013. Accepted: 28 September, 2013

\begin{abstract}
Bionia bella Mart. ex Benth. (Leguminosae, Papilionoideae) is restricted to the Atlantic Forest Biome in the Brazilian states of Minas Gerais and Espírito Santo. The vegetative and floral structures of the species were first described by George Bentham in 1837. The objective of the present study was to describe, for the first time, the fruits and seeds of the species, thus complementing the type material. From 2006 through 2010, we observed four populations of the species in a forest fragment near Serra do Brigadeiro State Park, located in the municipality of Araponga, in the state of Minas Gerais. Two of the four populations fruited only in 2010, and the other two populations produced no fruit during the study period. The fruits of B. bella are of the legume type, with explosive dehiscence, as in other species of the genus. The seeds are broad-elliptical, and the testa presents rugose ornamentation. Bionia bella is a good candidate for reproductive biology studies aimed at understanding reproductive difficulties in such species.
\end{abstract}

Key words: Fabaceae, Atlantic Forest, fruits, seeds

\section{Introduction}

The genus Bionia Mart. ex Benth. was established by George Bentham in 1837 and synonymized by the same author as Camptosema in 1840 (Bentham 1837; 1840). In the cladistic analysis of the subtribe Diocleinae, based on morphological characters, Queiroz et al. (2003) indicated that Camptosema was a polyphyletic genus, probably reflecting independent acquisitions of ornithophily in different lineages of Diocleinae. On the basis of that result, Queiroz (2008) reestablished the genus Bionia Mart. ex Benth., with five species, recognized by the inflorescences on brachyblasts; flowers with long tubular calyces that are larger than the lobes, externally glabrous; red, glabrous petals in a straight line, and without basal auricles; heteropolar pollen; and long-stipitate ovary. The five Bionia species-B. bella Mart. ex Benth.; B. coccinea Mart. ex Benth.; B. coriacea (Nees \& Mart.) Benth.; B. pedicellata (Benth.) L.P.Queiroz; and B. tomentosa (Benth.) L.P.Queiroz-are distributed throughout the Cerrado (Savanna), Caatinga (Shrublands) and Atlantic Forest biomes (Queiroz 2013).

The species Bionia bella was described by Bentham (1837) based on vegetative and floral materials, characterized by the presence of trifoliate leaves, woody stem base, slightly inconsistent branches and 2-pollicare flowers. In the seminal work Flora Brasiliensis, Bentham (1859) clas- sified B. bella Mart. ex Benth. as a synonym of Camptosema bellum (Mart. ex Benth.) Benth., placing it in the Section Bionia because it presented a colored, glabrous or sparsely pubescent calyx and acuminate lobes.

Bionia bella is known only from mountainous areas in the Brazilian states of Minas Gerais and Espírito Santo, being most often associated with the Serra da Mantiqueira Mountain Range (Queiroz 1999; 2013). The species has not been widely collected and is therefore poorly represented in herbaria. This might be attributable to its delicateness and its preference for shady environments, as well as to the fact that it is difficult to spot when not in bloom, as stated by Queiroz (1999). According to that author, its populations have been significantly reduced in some areas, especially in southern Minas Gerais, where it was collected only from the nineteenth century up through 1920 . Since the 1970s, specimens of B. bella have been collected only from within the Serra da Mantiqueira Mountain Range, which encompasses the Serra de Caparaó and Serra de Araponga, in Minas Gerais, as well as the Serra do Boi, in Espírito Santo. Therefore, the species has been listed as vulnerable to extinction in the wild.

From the publication of the initial study on Bionia bella until the last taxonomic revision carried out by Queiroz (1999), there have been no studies describing the fruits and seeds of the species. Lima et al. (2007) and Fernandes \&

\footnotetext{
${ }^{1}$ Universidade Federal de Viçosa, Departamento de Biologia Vegetal, Pós-doutorando em Botânica, Viçosa, MG, Brazil

${ }^{2}$ Universidade Federal de Viçosa, Departamento de Biologia Vegetal, Programa de Pós-Graduação em Botânica, Viçosa, MG, Brazil

${ }^{3}$ Author for correspondence: fernanbio@bol.com.br
} 
Garcia (2008), who conducted floristic studies, respectively, in Itacolomi State Park and in the vicinity of the Brigadeiro State Park, both of which are in Minas Gerais, noted that the flowers of $B$. bella did not form fruits. According to Lima et al. (2007), this failure to fruit suggests that this species has some reproductive difficulties. According to Queiroz (2008), species of the genus Bionia are ornithophilous, being visited mainly by hummingbirds.

This study presents the first description of the fruits and seeds of Bionia bella, 177 years after the initial study published by Bentham (1837). Our objective was to complement the type material, as well as to provide illustrations and images of the species.

\section{Material and methods}

\section{Study area}

The study was performed in a three-hectare fragment of semideciduous forest within the Atlantic Forest Biome (Veloso et al. 1991; AB'Sáber 2003). The fragment is on private land in the municipality of Araponga, Zona da Mata, $3.5 \mathrm{~km}$ from Serra do Brigadeiro State Park, in Minas Gerais $\left(42^{\circ} 32^{\prime}\right.$ to $42^{\circ} 27^{\prime} \mathrm{W} ; 20^{\circ} 38^{\prime}$ to $\left.20^{\circ} 43^{\prime} \mathrm{S}\right)$. A map of the area is available in Fernandes \& Garcia (2008). The study area has never been cleared, although timber has been extracted over the years for sustainable use by the local population.

According to the Köppen classification system, the climate of the region is temperate, ranging from type Cwb to type Cwa (mesothermal), characterized by warm-to-hot humid summers and warm dry winters, with an average annual temperature of $18^{\circ} \mathrm{C}$, monthly averages ranging from $10^{\circ} \mathrm{C}$ to $23^{\circ} \mathrm{C}$ (ENGEVIX 1995). Annual precipitation ranges from 1200 to $1800 \mathrm{~mm}$, with a rainy season from November to March and a dry season from May to September; fog formation is common at the higher elevations. The terrain is mountainous with slopes of $20-45 \%$, the average elevation is $1000 \mathrm{~m}$, and the predominant soil class is Oxisol (Golfari 1975).

\section{Methodology}

Individuals within four populations of Bionia bella were marked with yellow ribbons and observed from 2006 through 2010. Fruit-bearing branches were collected and processed for herbarium preservation by common methods (Bridson \& Forman 1999), after which they were deposited in the collection of the Universidade Federal de Viçosa (UFV, Federal University of Viçosa) Herbarium (code, VIC). In search of fruit of the species, we examined the collections of the herbaria of the Federal University of Juiz de Fora (code, CESJ), the Federal University of Ouro Preto (code, OUPR), the Research Institute of the Rio de Janeiro Botanical Garden (code, RB) and the (Bahia) State University of Feira de Santana (code, HUEFS), as well as that of the VIC.
The fruits and seeds were described based on the terminology established by Barroso et al. (1999) and in the studies conducted by Lersten (1981), Queiroz (1999), Kirkbride et al. (2003) and Queiroz et al. (2013). Illustrations of the fruits were obtained from dry and rehydrated material with the aid of a camera lucida attached to a stereomicroscope. The key to identification of species of the genus Bionia was based on the work of Queiroz (1999) and on the data collected in the present study.

For morphological and anatomical characterization of the seed testa, dried seed samples were extracted from the fruits, fixed on stubs with colloidal graphite and coated with gold in a sputter coater (FDU 010; Bal-Tec AG, Balzers, Liechtenstein) at the UFV Center for Microscopy and Microanalysis (UFV-CMM). To study the embryo, seeds were removed from the fruit and boiled for $10 \mathrm{~min}$, after which they were washed with tap water and the testae were removed. At the UFV Laboratory of Plant Anatomy, embryos were dehydrated in an ethanol series as described by Johansen (1940). Images of the testae and embryos were captured at the UFV-CMM with a scanning electron microscope (LEO 1430 VP; Carl Zeiss Ltd, Cambridge, England).

\section{Results and discussion}

Bionia bella Mart. ex Benth., Comm. Legum. Gen.: 66. 1837. Camptosema bellum (Mart. ex Benth.) Benth., Fl. Bras. 15(1): 156. 1859.

Fig. 1-8

Vines. Young sparsely-sericeous branches. Trifoliate leaves, stipules 2-2.2 $\mathrm{mm}$ long, lanceolate, sparselysericeous, deciduous; petiole $2-4.2 \mathrm{~cm}$ long, canaliculated, pubescent, rachis 4-9 $\mathrm{mm}$ long, canaliculated, sparsely sericeous; lateral leaflets symmetrical; terminal leaflet 2.6$5.3 \times 1.7-2.5 \mathrm{~cm}$ long, ovate-elliptic, acute apex, rounded base, adaxial and abaxial glabrescent faces. Pseudoracemose inflorescence, axillary; peduncle $0.7-1.5 \mathrm{~cm}$ long; rachis 2-3 mm long, striated, pubescent, 2-4 flowers. Flowers not resupinate; bracts 1-1.2 mm long, broad-ovate, pubescent; gamosepalous calyx, tubular, 27-28 mm long, tetramer, reddish; corolla dialypetalous, unguiculate, reddish, standard $4-5.4 \mathrm{~cm}$ long, wings $3.7-4.9 \mathrm{~cm}$ long, keel petals $3.9-4.9 \mathrm{~cm}$ long; 10 stamens, diadelphous, $34-41 \mathrm{~mm}$ long, isomorphic anthers; stipitate gynoecium; stem 10-15 mm long; ovary 10$12 \mathrm{~mm}$ long, sericeous, pluriovulate; stylus $9-13 \mathrm{~mm}$ long, straight; terminal stigma, truncated, glabrous. Fruits typical legumes, $10-11 \times 1-1.3 \mathrm{~cm}$, linear, stem $1.7-2 \mathrm{~cm}$, deciduous calyx, rarely persistent; epicarp obliquely nervate, light brown, adpressed, sericeous, with simple trichomes; apex acute, rostrate, cuneate base, asymmetric; woody valves, slightly constricted between seeds, straight or rarely winding margins, wound when open, 1-2 turns, elastic dehiscence; membranous endocarp, translucent between seeds. Seeds 5-7, broad-elliptic, 6-7.3 $\times$ 5-6 mm, flat, brown; testa not attached to the endocarp, leathery, without fracture lines, 


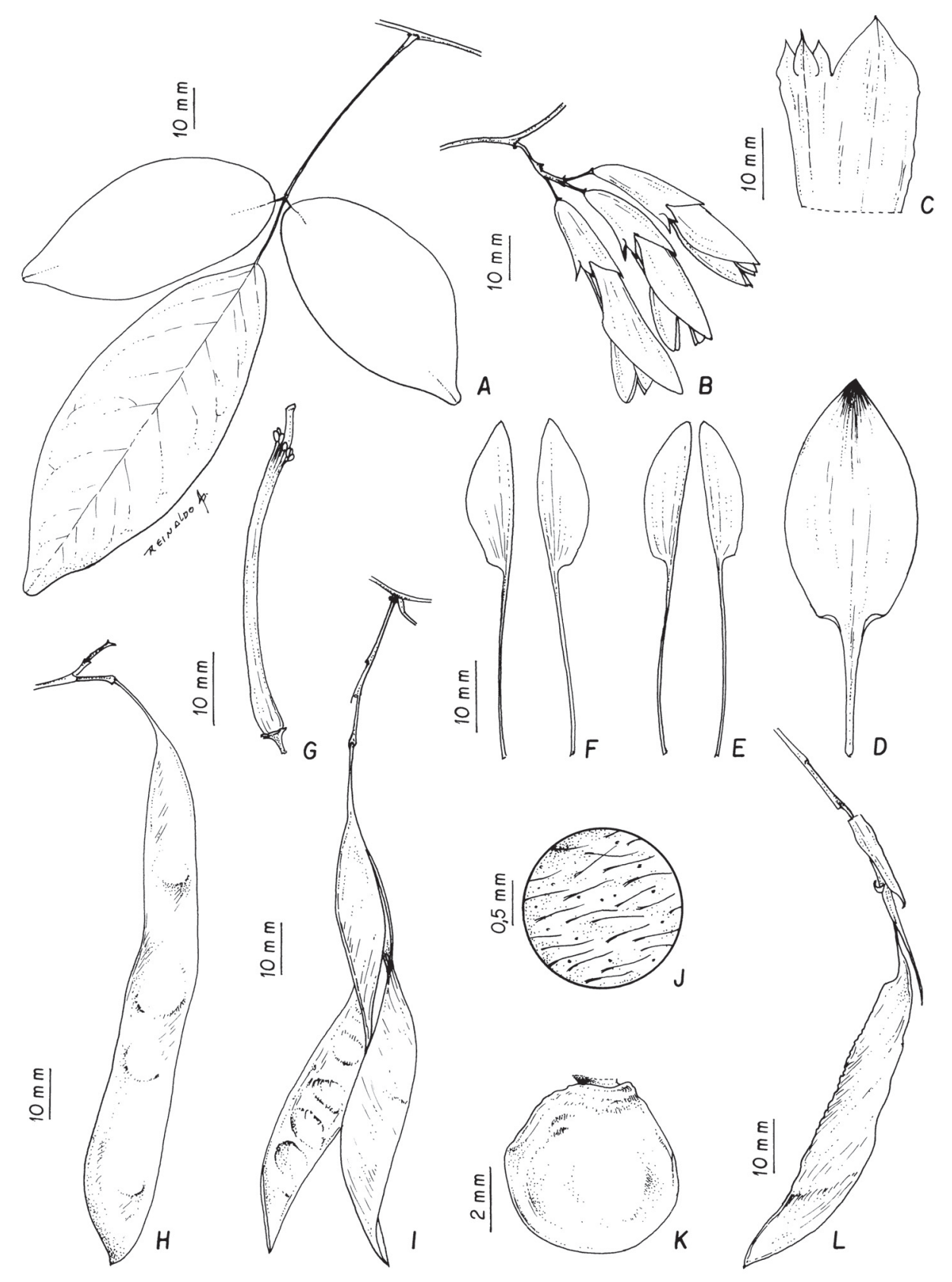

Figure 1. Expansion of the description of Bionia bella Mart. ex Benth. A. Branch with leaves. B. Inflorescence. C. Cup. D. Standard. E. wings. F. Keel petals. G. Androecium tube. H. Closed legume. I. Open legume. J. Indumentum outside the fruit. K. Seed. L. Aborted fruit.

A-G: Fernandes et al. 268; H-L: Fernandes 1322.

texture smooth, ornamentation crested; hilum 2.3-2.5 mm long, elliptical, subterminal; funiculus 2-2.5 mm long, laterally reduced aril; pale green embryo; radicle hidden in the cotyledons, truncated, rudimentary plumule.

Material examined: BRAZIL. Minas Gerais: Araponga, Fragmento da Eva, 01/V/2006, fl., Fernandes et al. 268 (VIC), 28/VI/2006, fr., Fernandes et al. 301 (VIC), 19/ IV/2010, fl. fr., Fernandes 1293 (VIC), 20/VII/2010, fr., Fernandes 1322 (VIC).
Bionia bella differs from other species of the genus Bionia because of its semi-woody habitat, reduced number of flowers (2-4) per inflorescence and fruit with acute apex. According to Queiroz (1999), B. bella is the species presenting the greatest reduction in vegetative and inflorescence characteristics, and also has a delicate habit occurring as a voluble vine. B. bella can be identified by the following characters: 
1. Simple or unifoliolate leaves.

2. Petiole present, $0.6-6.5 \mathrm{~cm}$ in length

B. coriacea.

2. Petiole absent, leaves attached to the stem only by a pulvinus of $\leq 0.5 \mathrm{~cm}$ in length.

3. Leaves with obtuse base and abaxial surface velutinous, erect trichomes, cinereous; fruits with velutinous indumentum

B. pedicellata.

3. Leaves with strongly cordate base and abaxial surface sericea, or if obtuse, then glabrescent leaflets; fruits with sericeous indumentum

B. coccinea.

1. Trifoliate leaves.

4. Voluble vines, semi-woody; non-woody inflorescences on brachyblasts; fruits with sericeous indumentum

B. bella.

4. Shrubs or virgate subshrubs, erect or scandent, with strongly woody branches; woody inflorescences on brachyblasts, fruit with puberulent indumentum.

5. Glabrous leaflets

B. coriacea.

5. Tomentose or fleecy leaflets

B. tomentosa.

This study presents the first records of fruits and seeds of Bionia bella (Fig. 1 and 3). As previously mentioned, the four populations delineated in the study area were monitored for five years (from 2006 through 2010). During the study period, two of the populations produced no fruit, and the two remaining populations produced fruits and seeds only during the flowering of 2010. Fruit were produced mainly from the first flowers of the inflorescences, whereas flowers located in the middle and terminal regions of the inflorescences developed partial fruits that were aborted before they reached maturity.

Fruits are of the legume type, flat when closed and coiled when open, with woody valves and cuneate bases, which, according to Queiroz (1999), is common to all species of the genus Bionia with known fruits. Bionia bella is the only species presenting an acute apex, other species of the genus having truncate or obtuse apices (Tab. 1).

The aborted fruits of Bionia bella always presented a persistent calyx, wrinkled surface and only signs of seeds (Fig. 1). According to Fenner \& Thompson (2005), the main causes for the loss of fruit include pollination inefficiency and lack of resources from the mother plant to mature fertilized eggs, abortion being due to deleterious gene combinations.

The seeds of Bionia bella differ from those of other species of the genus by being broad-elliptic (Fig. 4), with an elliptical hilum, the seed and hilum both being oblong in the other species. With the exception of $B$. pedicellata, the seeds of all Bionia species have been described (Bentham 1840; Queiroz 1999).

The testae of the seeds are not adhered to the endocarps or the embryos, have a leathery consistency, no fracture lines, a smooth texture and microscopically crested ornamentation (Fig. 4 and 5). However, when observed by the naked eye it may be regarded as smooth, whereas it can appear dotted when observed under stereomicroscopy. Kirkbride et al. (2003) in the study of fruits and seeds of genera of the subfamily Papilionoideae (Leguminosae), included species of the tribe Phaseoleae. Among the species studied by those authors were Cymbosema roseum Benth. and Camptosema rubicundum Hook. \& Arn., which present rugose testae. According to Queiroz (2013), those species have testa with crested ornamentation as in Bionia bella. The importance of testa characters for distinguishing species can be found in the work of Queiroz et al. (2013), which separates the Tephrosia species (Leguminosae, Papilionoideae, Millettieae) in the neotropics based on seed characters, especially those related to the texture and ornamentation of the testa.

In the specimens of Bionia bella examined here, the aril is greatly reduced and does not completely cover the funiculus (Fig. 6). According to Barroso et al. (1999), the aril

Table 1. Morphological comparison of fruits and seeds among species of the genus Bionia Mart. ex Benth. (Leguminosae, Papilionoideae).

\begin{tabular}{lccccc}
\hline \multirow{2}{*}{ Species } & \multicolumn{3}{c}{ Fruit } & & Seed \\
\cline { 2 - 5 } & Apex & Margin & Indumentum & Shape & Hilum \\
\hline Bionia bella Mart. ex Benth. ${ }^{*}$ & acute & straight or sinuous & sericeous & broad-elliptical & elliptical \\
B. coccinea Mart. ex Benth.** & truncated & straight & sericeous & oblong & oblong \\
B. coriacea (Nees \& Mart.) Benth. ${ }^{* *}$ & obtuse & straight & puberulent & oblong & oblong \\
B. pedicellata (Benth.) L.P.Queiroz & truncated & straight & velutinous & - & - \\
B. tomentosa (Benth.) L.P.Queiroz & obtuse & straight & puberulent & oblong-ovate & oblong \\
\hline
\end{tabular}

${ }^{*}$ Present study; ${ }^{* *}$ Queiroz (1999). 

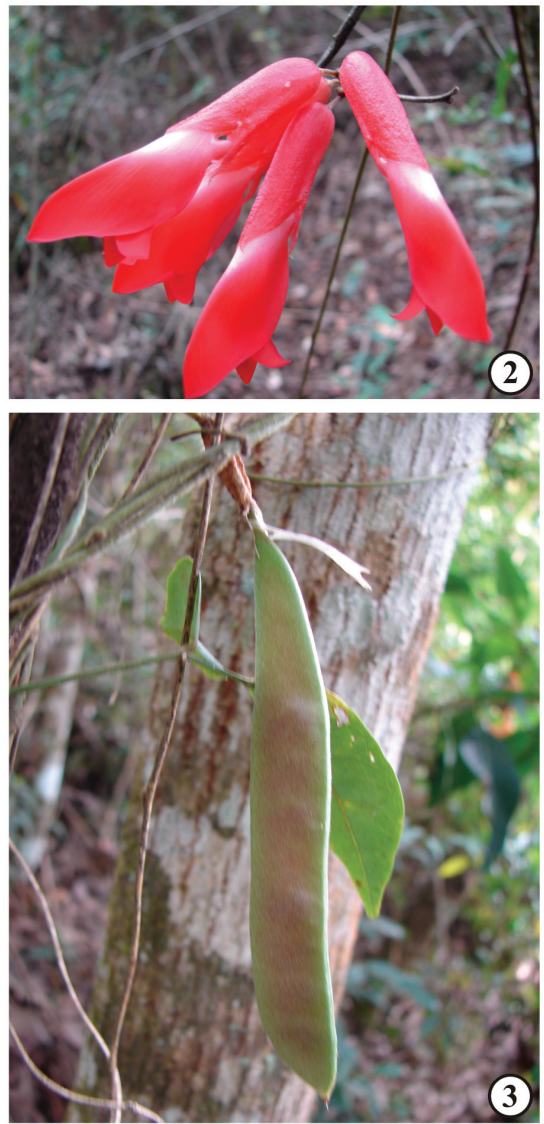

Figures 2-3. Photos of Bionia bella Mart. ex Benth. in the field. Fig. 2. Branch with inflorescence; Fig. 3. Branch with fruit. is a fleshy projection originating from the extremity of the funiculus, near the hilar region. The cotyledons are divided almost to the middle region, hiding the radicle (Fig. 7) and the plumule, which is considered rudimentary (Fig. 8). Paulino et al. (2010) conducted morphological and anatomical studies of the seeds and seedlings of Indigofera species (Leguminosae, Papilionoideae, Indigofereae). Among the characters with taxonomic relevance for the species of the genus, the authors cited the size and ornamentation of the hilum and the surface ornamentation of the cotyledons.

In conclusion, the fruits and seeds of Bionia bella have several characters in common with other species of Bionia but show major differences that facilitate the recognition of the species. There is a need for reproductive biology studies of this species, in order to understand which factors limit the formation of fruit.

\section{Acknowledgments}

The authors are grateful the owners of the forest fragment under study; to Lívia C. de Siqueira, Carolina B. M. Pellucci and Rafael Polizel, for their assistance in the fieldwork; to Reinaldo Pinto, for providing the botanical illustrations; to Gilmar Valente and Patrícia Fonseca, of the UFV-CMM, for assisting in the microscopy; to the staff of the UFV Laboratory of Plant Anatomy, for assisting in the morphological studies; and to Prof. Jefferson Prado at the Botanical Institute of São Paulo, for his contribution to the botanical nomenclature. To Conselho Nacional de Desenvolvimento Científico e
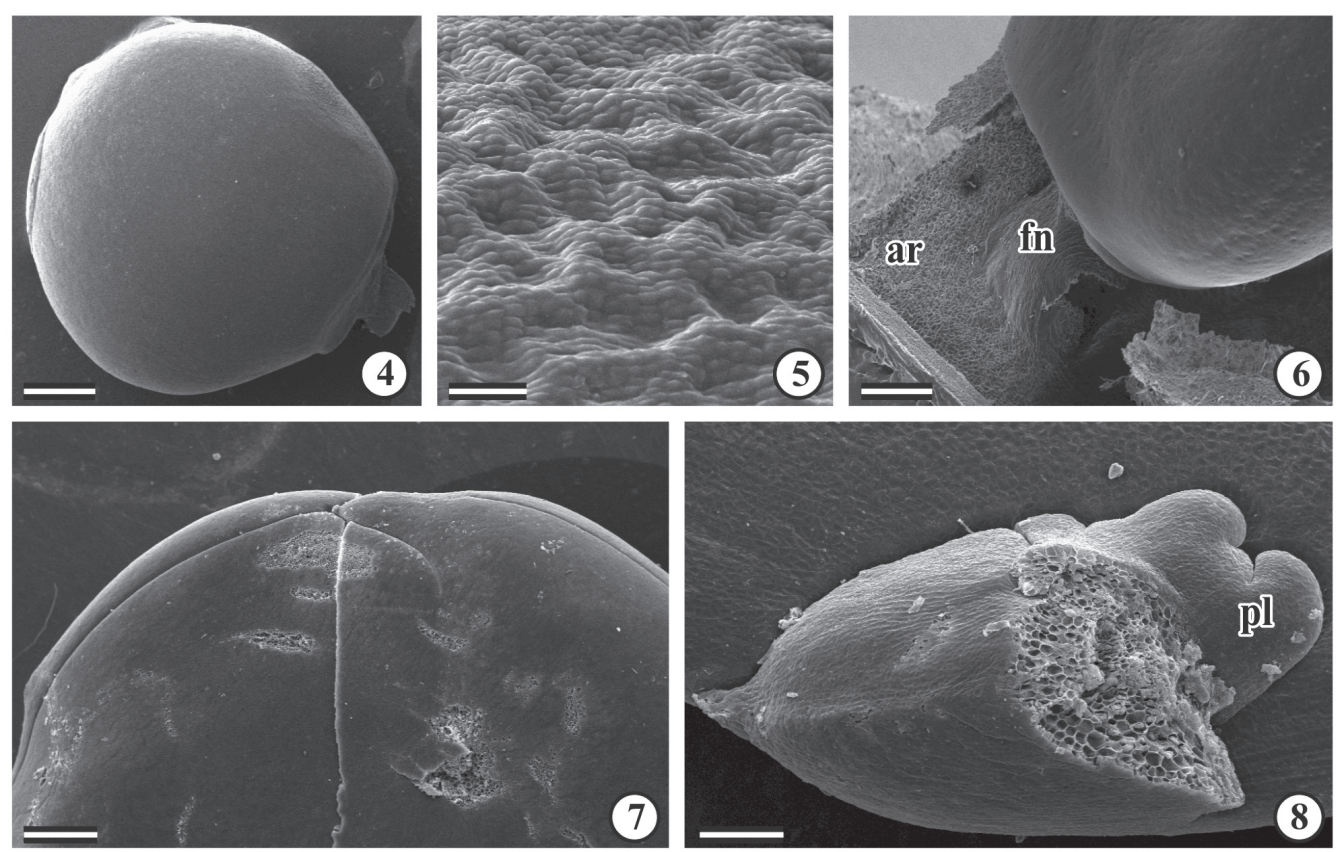

Figures 4-8. Morphology and anatomy of a seed of Bionia bella Mart. ex Benth., under scanning electron microscopy. Fig. 4. Seed; Fig. 5. Ornamentation of the testa; Fig. 6. Aril and funiculus; Fig. 7. Part of the cotyledon; Fig. 8. Radicle.

Scale bars: $1 \mathrm{~mm}$ (Fig. 4); $30 \mu \mathrm{m}$ (Fig. 5); $450 \mu \mathrm{m}$ (Fig. 6); $450 \mu \mathrm{m}$ (Fig. 7); $100 \mu \mathrm{m}$ (Fig. 8). ar - aril; fn - funiculus; pl - plumule. 
Tecnológico (CNPq), and the Fundação de Amparo à Pesquisa do Estado de Minas Gerais (FAPEMIG). This work received technical and financial support, respectively, from the Zona da Mata (Minas Gerais) Centro de Tecnologias Alternativas (CTA, Center for Alternative Technologies) and the UFV Graduate Program in Botany.

\section{References}

AB'Sáber, A.N. 2003. Os domínios de natureza no Brasil: potencialidades paisagísticas. São Paulo, Ateliê Editorial.

Barroso, G.M.; Morim, M.P.; Peixoto, A.L. \& Ichasso, C.L.F. 1999. Frutos e sementes: morfologia aplicada à sistemática de dicotiledôneas. Viçosa, Editora UFV.

Bentham, G. 1837. Commentationes de Leguminosarum Generibus. Vindobonae, Typis J.B.Sollinger.

Bentham, G. 1840. Contributions towards a flora of South America - enumeration of plants collected by Mr. Schomburgk in British Guiana. Journal of Botany 2(10): 60 .

Bentham, G. 1859. Leguminosae. In: Martius, C.F.P. (Ed.). Flora Brasiliensis 15(part. 1): 1-350.

Bridson, D. \& Forman, L. 1999. The herbarium: handbook. 3 ed. Kew, Royal Botanic Gardens.

ENGEVIX. 1995. Caracterização do meio físico da área autorizada para criação do Parque Estadual da Serra do Brigadeiro: relatório técnico final dos estudos - 8296- RE-H4-003/94. Belo Horizonte, IEF.

Fenner, M. \& Thompson, K. 2005. The ecology of seeds. Cambridge, University press.

Fernandes, J.M. \& Garcia, F.C.P. 2008. Leguminosae em dois fragmentos de floresta estacional semidecidual em Araponga, Minas Gerais, Brasil: arbustos, subarbustos e trepadeiras. Rodriguésia 59(3): 525-546.

Golfari, L. 1975. Zoneamento Ecológico do Estado de Minas Gerais para reflorestamento. Belo Horizonte, CPFRC.
Johansen, D.A. 1940. Plant microtechnique. New York, McGraw-Hill Book.

Kirkbride, J.H.; Gunn, C.R. \& Weitzman, A.L. 2003. Fruits and seeds of genera in the subfamily Faboideae (Fabaceae). Tech. Bull. 1890. United States Department of Agriculture. Washington DC, Agricultural Research Service.

Lersten, N.R. 1981. Testa topography in Leguminosae, subfamily Papilionoideae. Proceedings of the Iowa Academy of Science 88:180-191.

Lima, L.C.P.; Garcia, F.C.P. \& Sartori, Â.L.B. 2007. Leguminosae nas florestas estacionais do Parque Estadual do Itacolomi, Minas Gerais, Brasil: ervas, arbustos, subarbustos, lianas e trepadeiras. Rodriguésia 58(2): 331-358.

Paulino, J.V.; Pessine, E. \& Teixeira, S.P. 2010. Estudos morfoanatômicos da semente e da plântula de espécies de Anileiras (Indigofera L., Leguminosae). Acta Botanica Brasilica 24(1): 1-7.

Queiroz, L.P. 1999. Sistemática e filogenia do gênero Camptosema W.J.Hook. \& Arn. (Leguminosae: Papilionoideae: Phaseoleae). Tese de Doutorado, Universidade de São Paulo, São Paulo.

Queiroz, L.P. 2008. Re-establishment, synopsis and new combinations in the genus Bionia Mart. ex Benth. (Leguminosae: Papilionoideae). Neodiversity 3: 13-18.

Queiroz, L.P. 2013. Bionia. In: Lista de Espécies da Flora do Brasil. Jardim Botânico do Rio de Janeiro. http://floradobrasil.jbrj.gov.br/jabot/ floradobrasil/FB101047. (Acesso em 22/06/2013).

Queiroz, L.P.; Fortunato, R.H. \& Giulietti, A.M. 2003. Phylogeny of the Diocleinae (Papilionoideae: Phaseoleae) based on morphological characters. Pp. 303-324. In: Klitgaard, B.B. \& Bruneau, A. (Ed.). Advances in Legume Systematics, Part 10. Higher Level Systematics. Kew, Royal Botanic Gardens.

Queiroz, R.T.; Tozzi, A.M.G.A. \& Lewis, G.P. 2013. Seed morphology: an addition to the taxonomy of Tephrosia (Leguminosae, Papilionoideae, Millettieae) from South America. Plant Systematics and Evolution 299:459-470.

Veloso, H.P.; Rangel-Filho, A.L.R. \& Lima, J.C.A. 1991. Classificação da vegetação brasileira, adaptada a um sistema universal. Rio de Janeiro, IBGE. 